\title{
Comparison of One-Tube Nested-PCR and PCR-Reverse Blot Hybridization Assays for Discrimination of Mycobacterium tuberculosis and Nontuberculous Mycobacterial Infection in FFPE tissues
}

\author{
Sung-Bae Park ${ }^{1,2, \S, *}$, Heechul Park ${ }^{1,2, \S, *}$, Jinyoung Bae ${ }^{1,2, *}$, Jiyoung Lee $^{3, * *}$, Ji-Hoi Kim $^{4, * * * * * * * * *}$, \\ Mi Ran Kang ${ }^{4, * * *}$, Dongsup Lee ${ }^{5, * * * *}$, Ji Young Park ${ }^{6, * * * * *}$, Hee-Kyung Chang ${ }^{7, \dagger, * * * * *}$ \\ and Sunghyun Kim ${ }^{1,2, ;, * * * *}$ \\ ${ }^{1}$ Department of Clinical Laboratory Science, College of Health Sciences, \\ Catholic University of Pusan, Busan 46252, Korea, \\ ${ }^{2}$ Clinical Trial Specialist Program for In Vitro Diagnostics, Brain Busan 21 Plus Program, \\ Graduate School, Catholic University of Pusan, Busan 46252, Korea \\ ${ }^{3}$ Department of Biomedical Laboratory Science, College of Health Sciences, \\ Yonsei University, Wonju 26493, Korea \\ ${ }^{4} Y D$ R\&D Center, YD Diagnostics, Yongin 17127, Korea \\ ${ }^{5}$ Department of Biomedical Laboratory Science, Hyejeon College, Hongsung 32244, Korea \\ ${ }^{6}$ Department of Internal Medicine, Kosin University Gospel Hospital, Busan 49267, Korea \\ ${ }^{7}$ Department of Pathology, Kosin University College of Medicine, Busan 49267, Korea
}

\begin{abstract}
Currently, molecular diagnostic assays based on nucleic acid amplification tests have been shown to effectively detect mycobacterial infections in various types of specimen, however, variable sensitivity was shown in FFPE samples according to the kind of commercial kit used. The present study therefore used automated PCR-reverse blot hybridization assay (REBA) system, REBA Myco-ID HybREAD $480^{\circledR}$, for the rapid identification of Mycobacterium species in various types of human tissue and compared the conventional one-tube nested-PCR assay for detecting Mycobacterium tuberculosis (MTB). In conventional nested-PCR tests, 25 samples (48\%) were MTB positive and 27 samples (52\%) were negative. In contrast, when conducted PCR-REBA assay, 11 samples (21\%) were MTB positive, 20 samples (39\%) were NTM positive, 8 samples (15\%) were MTB-NTM double positive, and 13 samples (25\%) were negative. To determine the accuracy and reliability of the two molecular diagnostic tests, the one-tube nested-PCR and PCR-REBA assays, were compared with histopathological diagnosis in discordant samples. When conducted nested-PCR assay, 10 samples (59\%) were MTB positive and seven samples $(41 \%)$ were negative. In contrast, when conducted PCR-REBA test, three samples (17\%) were MTB positive, 10 samples (59\%) were NTM positive and four samples (24\%) were negative. In conclusion, the automated PCR-REBA system proved useful to identify Mycobacterium species more rapidly and with higher sensitivity and specificity than the conventional molecular assay, one-tube nested-PCR; it might therefore be the most suitable tool for identifying Mycobacterium species in various types of human tissue for precise and accurate diagnosis of mycobacterial infection.
\end{abstract}

Key Words: Tuberculosis, Mycobacterium infections, Molecular typing, Nontuberculous mycobacteria, Paraffin embedding

Received: October 2, 2019 / Revised: November 15, 2019 / Accepted: November 25, 2019

$\S_{\text {Equal contributors. }}$

* Graduate student, ${ }^{* *}$ Post-Doctor, ${ }^{* * *}$ Researcher, ${ }^{* * *}$ Professor, ${ }^{* * * * *}$ Medical Doctor.

† Corresponding author: Sunghyun Kim. Department of Clinical Laboratory Science, College of Health Sciences, Catholic University of Pusan, Busan 46252, Korea.

Tel: +82-51-510-0560, Fax: +82-51-510-0568, e-mail: shkim0423@cup.ac.kr

(C) The Korean Society for Biomedical Laboratory Sciences. All rights reserved.

(c) This is an Open Access article distributed under the terms of the Creative Commons Attribution Non-Commercial License (http://creativecommons.org/licenses/by-nc/3.0/) which permits unrestricted non-commercial use, distribution, and reproduction in any medium, provided the original work is properly cited. 
Tuberculosis (TB) is a lethal infectious disease caused by Mycobacterium tuberculosis (MTB) which continues to pose serious problems worldwide (Jung et al., 2019). According to a World Health Organization (WHO) report, approximately 10 million people suffer health problems caused by TB annually (World Health Organization, 2017). In addition, the numbers of human immunodeficiency virus (HIV)infected people with TB and/or multi-drug resistant (MDR)TB have also increased, making it difficult to treat and control the TB in these situations (Vidyaraj et al., 2017).

Globally, the most widely used conventional method for detecting MTB in formalin-fixed paraffin-embedded (FFPE) tissue is an acid-fast bacilli (AFB) stain. This is a rapid and simple method; however, FFPE specimens can contain low bacterial load, and the granuloma formation and necrosis caused by mycobacteria can be also found in other bacterial and fungal infections (Bao et al., 2018). Additionally, AFB staining displays low sensitivity in the detection of MTB and the method cannot differentiate MTB from nontuberculous mycobacteria (NTM) species (Lee et al., 2011). Alternative diagnostic tools are therefore required for the rapid identification of mycobacterial species which is very important for treatment of the infections they cause (Azov et al., 2005).

Recently, molecular diagnostic assays based on nucleic acid amplification tests, such as real-time polymerase chain reaction (PCR), line probe assay (LPA), and reverse blot hybridization (REBA) assays, have been shown to effectively identify mycobacterial species in various respiratory specimens and culture samples (Sun et al., 2009). A number of previous studies have used FFPE tissue to evaluate these diagnostic assays and report higher specificity (99\%) but variable sensitivity according to the kind of commercial kit used (Stauffer et al., 1998; Jang et al., 2003; Yang et al., 2006; Munkhdelger et al., 2013).

In the present study, a total of 52 FFPE human tissue samples including lung, lymph node, skin, bronchus, and other various tissue were analyzed using the automated PCR-REBA system, REBA Myco-ID HybREAD $480^{\circledR}$, in order to compare the conventional one-tube nested-PCR assay.

A total of 52 FFPE human tissue samples were obtained between 2011 and 2017 from the Department of Pathology at Kosin University Gospel Hospital (Busan, Republic of Korea), and this study was performed by approval of institutional review board (IRB No. KUGH 2017-11-042). Tissue sections $4 \mu \mathrm{m}$ thick were cut from the paraffin blocks and ten paraffin sections were placed in sterile $1.5 \mathrm{~mL}$ tubes. For deparaffination and genomic DNA (gDNA) extraction, a QIAamp DNA FFPE Tissue Kit (Qiagen, Hilden, Germany) was used according to the manufacturer's instructions. The extracted genomic DNA was measured concentration and purity by NanoDrop 2,000 (Thermo Fisher Scientific, Waltham, MA, USA).

The one-tube nested-PCR assay was conducted using MTB PCR Kit (Biosewoom, Seoul, Republic of Korea) according to manufacturer's instruction. And, $5 \mu \mathrm{L}$ aliquot of the PCR product was resolved on $1.5 \%$ Tris Borate EDTA agarose gel. The products were visualized by ultraviolet transillumination compared to the positive control. The first PCR band was revealed at 256 bp and the second PCR band was revealed at $181 \mathrm{bp}$. The PCR-REBA assay, REBA

Table 1. Population characteristics

\begin{tabular}{llc}
\hline \hline & Characteristics & $\begin{array}{c}\text { No. of } \\
\text { samples, } \mathrm{n}(\%)\end{array}$ \\
\hline $\begin{array}{l}\text { Age } \\
\text { (median }=51.7\end{array}$ & $<30$ 's & $11(21.1)$ \\
SD+- 16.3 yrs, & $40 \sim 50$ 's & $21(40.4)$ \\
range $=17-87)$ & $>60$ 's & $20(38.5)$ \\
Sex & Male & $35(67.3)$ \\
& Female & $17(32.7)$ \\
Locations & Colon & $14(26.9)$ \\
& Lung & $13(25.0)$ \\
& Ileum & $7(13.6)$ \\
& Lymph node & $6(11.6)$ \\
& Skin & $3(5.8)$ \\
& Ear & $2(3.8)$ \\
& Bronchus & $1(1.9)$ \\
& Testis & $1(1.9)$ \\
& Tendon & $1(1.9)$ \\
Kidney & $1(1.9)$ \\
& Appendix & $1(1.9)$ \\
Soft tissue (hand) & $1(1.9)$ \\
Finger joint & $1(1.9)$ \\
\hline Total & $52(100)$ \\
\hline
\end{tabular}


Table 2. Comparison between one-tube nested-PCR and automated PCR-REBA result

\begin{tabular}{|c|c|c|c|c|}
\hline & & \multicolumn{3}{|c|}{ Automated PCR-REBA } \\
\hline & & MTB, n (\%) & NTM, n (\%) & Negative, n (\%) \\
\hline \multirow{6}{*}{ One-tube nested-PCR } & MTB, n (\%) & $12(23 \%)$ & $9(17 \%)$ & $4(8 \%)$ \\
\hline & Negative, n (\%) & $7(14 \%)$ & $11(21 \%)$ & $9(17 \%)$ \\
\hline & Total, n (\%) & $19(37 \%)$ & $20(38 \%)$ & $13(25 \%)$ \\
\hline & PPV, \% (n) & $63.2 \%(12 / 19)$ & $55.0 \%(11 / 20)$ & - \\
\hline & NPV, \% (n) & - & - & $69.2 \%(9 / 13)$ \\
\hline & Concordance, \% (n) & & $61.5 \%(32 / 52)$ & \\
\hline
\end{tabular}

MTB: Mycobacterium tuberculosis, NTM: Nontuberculous mycobacteria, PPV: Positive predictive value, NPV: Negative predictive value

Table 3. Comparison of results from the one-tube nested-PCR and automated PCR-REBA assays with histopathological diagnosis in discordant samples

\begin{tabular}{|c|c|c|c|c|}
\hline Histopathological diagnosis & \multicolumn{2}{|c|}{ One-tube nested PCR, n (\%) } & \multicolumn{2}{|c|}{ Automated PCR-REBA, n (\%) } \\
\hline \multirow{3}{*}{$\mathrm{TBC}(\mathrm{n}=17)$} & \multirow{2}{*}{ MTB } & \multirow{2}{*}{$10(59 \%)$} & МТB & $3(17 \%)$ \\
\hline & & & NTM & $10(59 \%)$ \\
\hline & Negative & $7(41 \%)$ & Negative & $4(24 \%)$ \\
\hline \multirow{3}{*}{ Chronic inflammation $(n=13)$} & \multirow{2}{*}{ МТВ } & \multirow{2}{*}{$3(23 \%)$} & MTB & $2(15 \%)$ \\
\hline & & & NTM & $11(85 \%)$ \\
\hline & Negative & $10(77 \%)$ & Negative & $0(0 \%)$ \\
\hline
\end{tabular}

TBC: Tubercle, MTB: Mycobacterium tuberculosis, NTM: Non-tuberculous mycobacteria

Myco-ID ${ }^{\circledR}$, was used according to the manufacturer's instructions to rapidly identify Mycobacterium species in various tissue samples. All processes and data interpretation were completed by HybREAD 480 system $^{\circledR}$.

The characteristics of the patients involved in this study are shown in Table 1. The mean age of the enrolled subjects was 51.7 years ( 17 to 87 years) and the male-to-female ratio was 35:17 (67.3\%:32.7\%). FFPE tissue was obtained from several types of organ including colon $(n=14,26.9 \%)$, lung $(n=13,25 \%)$, ileum $(n=7,13.6 \%)$, lymph node $(n=6,11.6 \%)$, skin $(n=3,5.8 \%)$, ear $(n=2,3.8 \%)$, and bronchus, testis, tendon, kidney, appendix, soft tissue, and finger joint (all $\mathrm{n}=1,1.9 \%$ ).

To evaluate the automated diagnostic performance of the REBA Myco-ID ${ }^{\circledR}$ assay, its results were compared with those from the conventional one-tube nested-PCR tests for detecting MTB and NTM infection. In conventional one-tube nested-PCR tests, among the 52 samples, 25 samples (48\%) were MTB positive and 27 samples (52\%) were negative. In contrast, when conducted the PCR-REBA assay, among the 52 samples, 11 samples (21\%) were MTB positive, 20 samples $(39 \%)$ were NTM positive, 8 samples $(15 \%)$ were MTB-NTM double positive, and 13 samples (25\%) were negative. The positive predictive values (PPVs) for MTB, NTM and negative predictive value (NPV) of REBA Myco$\mathrm{ID}^{\circledR}$ test were $63.2 \%, 55.0 \%$ and $69.2 \%$, respectively (Table 2). The overall coincidence rate of the assays was $61.5 \%$.

To determine the accuracy and reliability of the two molecular diagnostic tests, results from those two assays, the one-tube nested-PCR and PCR-REBA assays, were compared with histopathological diagnosis in discordant samples (Table 3). Among the 17 tubercle samples, when conducted the conventional nested-PCR test, 10 samples (59\%) were MTB positive and seven samples $(41 \%)$ were negative. In contrast, when conducted PCR-REBA assay, three samples (17\%) were MTB positive, 10 samples (59\%) were NTM positive and four samples (24\%) were negative. Likewise, among the 13 chronic inflammation samples, when conducted the one-tube nested-PCR test, three samples (23\%) were MTB positive and 10 samples (77\%) were negative. 
On the other hand, when conducted PCR-REBA assay, two samples (15\%) were MTB positive and 11 samples (85\%) were NTM positive.

TB remains a serious health problem in the Republic of Korea (Kim et al., 2018). Moreover, cases of NTM infection have been misdiagnosed as TB and treated unnecessarily (Nasiri et al., 2018). Accurate diagnosis of mycobacterial infection by MTB and other NTM species is therefore required.

Of the 25 samples that tested MTB positive in one-tube nested-PCR assay, 12 cases (48\%) were similarly identified as MTB by the PCR-REBA assay; however, nine cases $(36 \%)$ were identified as NTM and four $(16 \%)$ as negative for any mycobacterial infection. This means that where nested-PCR only identified MTB, the REBA Myco-ID HybREAD $480^{\circledR}$ system identified MTB and NTM. In addition, it is thought that existing nested-PCR techniques might amplify the nucleotide sequence which can cause crossreaction between NTM and MTB. Among the 27 samples that returned negative results in one-tube nested-PCR, nine cases (33\%) were also negative for mycobacterial infection in PCR-REBA; however, seven cases (26\%) were identified as MTB and $11(41 \%)$ as NTM. Additional DNA sequence analysis with discordant samples is required in both assays to compare their accuracy as this could not be confirmed because of the limited template DNA samples in the present study.

In conclusion, the conventional one-tube nested-PCR assay provides a more sensitive in detecting MTB, however, cannot discriminate between MTB and NTM species. However, the automated REBA Myco-ID HybREAD $480^{\circledR}$ system provided a rapid and effective method of simultaneously detecting MTB, NTM species, and MTB-NTM coinfection in various tissue samples. Although the system is more expensive than conventional assays, its overall economy and time consumption are advantageous. The REBA Myco-ID HybREAD $480^{\circledR}$ system can therefore provide accurate identification of mycobacterial species for the effective antibiotic treatment of infection. Nevertheless, further evaluation should be performed with larger volumes of varied clinical samples.

\section{ACKNOWLEDGEMENT}

This study was supported by Basic Science Research Program through the National Research Foundation of Korea (NRF) funded by the Ministry of Education (NRF2016R1C1B108888) and Brain Busan 21 Plus (BB21+) Project.

\section{CONFLICT OF INTEREST}

No potential conflict of interest relevant to this article was reported.

\section{REFERENCES}

Azov AG, Koch J, Hamilton-Dutoit SJ. Improved diagnosis of mycobacterial infections in formalin-fixed and paraffinembedded sections with nested polymerase chain reaction. APMIS. 2005. 113: 586-593.

Bao JR, Clark RB, Master RN, Shier KL, Eklund LL. Acid-fast bacterium detection and identification from paraffin-embedded tissues using a PCR-pyrosequencing method. J Clin Pathol. 2018. 71: 148-153.

Jang SJ, Kang JS, Kim JH, Cho SS, Park G, Moon DS, Park YJ. Comparison of Three Radiolabeled Probes for PCR-Hybridization to Detect Mycobacterium tuberculosis. Korean J Lab Med. 2003. 23: 25-31.

Jung H, Bang HI, Choi TY. Evaluation of the Effectiveness of a Re-decontaminating Process with Bacterial Contaminated Specimens Showing a Positive MGIT Signal for the Detection of Mycobacteria. Korean J Clin Lab Sci. 2019. 51: 171-176.

Kim K, Yang JS, Choi H, Kim H, Park SH, Jeon SM, Lim NR, Kim CK. A molecular epidemiological analysis of tuberculosis trends in South Korea. Tuberculosis (Edinb). 2018. 111: 127 -134 .

Lee, HS, Park KU, Park JO, Chang HE, Song J, Choe G. Rapid, sensitive, and specific detection of Mycobacterium tuberculosis complex by real-time PCR on paraffin-embedded human tissues. J Mol Diagn. 2011. 13: 390-394.

Munkhdelger, J, Wang HY, Choi Y, Wairagu PM, Lee D, Park S, Kim S, Jeon BY, Lee H, Park KH. Identification of Mycobacterium species in FFPE granulomatous lymphadenitis tissue using REBA Myco-ID ${ }^{\circledR}$. Int J Tuberc Lung Dis. 2013. 17: 898 -902 .

Nasiri MJ, Dabiri H, Fooladi AAI, Amini S, Hamzehloo G, Feizabadi MM. High rates of nontuberculous mycobacteria isolation 
from patients with presumptive tuberculosis in Iran. New Microbes New Infect. 2018. 21: 12-17.

Stauffer F, Haber H., Rieger A, Mutschlechner R, Hasenberger P, Tevere VJ, Young KK. Genus level identification of mycobacteria from clinical specimens by using an easy-to-handle Mycobacterium-specific PCR assay. J Clin Microbiol. 1998. 36: 614-617.

Sun JR, Lee SY, Perng CL, Lu JJ. Detecting Mycobacterium tuberculosis in Bactec MGIT 960 cultures by inhouse IS6110based PCR assay in routine clinical practice. J Formos Med Assoc. 2009. 108: 119-125.

Vidyaraj CK, Chitra A, Smita S, Muthuraj M, Govindarajan S, Usharani B, Anbazhaqi S. Prevalence of rifampicin-resistant Mycobacterium tuberculosis among human-immunodeficiency -virus-seropositive patients and their treatment outcomes. J Epidemiol Glob Health. 2017. 7: 289-294.
World Health Organization 2017. WHO Global tuberculosis report. 2017.

Yang HY, Lee HJ., Park SY, Lee KK, Suh JT. Comparison of Inhouse Polymerase Chain Reaction Assay with Conventional Techniques for the Detection of Mycobacterium tuberculosis. Korean J Lab Med. 2006. 26: 174-178.

https://doi.org/10.15616/BSL.2019.25.4.426

Cite this article as: Park SB, Park $\mathrm{H}$, Bae J, Lee J, Kim JH, Kang MR, Lee D, Park JY, Chang HK, Kim S. Comparison of One-Tube Nested-PCR and PCRReverse Blot Hybridization Assays for Discrimination of Mycobacterium tuberculosis and Nontuberculous Mycobacterial Infection in FFPE tissues. Biomedical Science Letters. 2019. 25: 426-430. 